\title{
New Towns in Medieval France and Nature of Institutions
}

\author{
Marie-Christine Thaize Challier \\ University of Paris 2, CNRS, Ermes \\ 12 Place du Panthéon, 75230 Paris cedex 05, France \\ Tel: 33-1-4441-8961Ｅ-mail: marie-christine.thaize@u-paris2.fr
}

Received: February 11, $2011 \quad$ Accepted: March 8, $2011 \quad$ doi:10.5539/res.v3n1p13

\begin{abstract}
Urban development was a key phenomenon in medieval Western Europe. This paper focuses on the relationship between the institutions and the new towns set up in France at that time. It interprets the institutional evolution on the basis of the actions of communities' founders (kings or overlords) and dwellers to govern the transition through urban constitutions furthering civil, economic, administrative, and political laws. It highlights institutions by which the royal government acquired territory and increased its influence at the expense of feudal lords. It shows that some formal and informal institutions prevailed at a local level to provide the incentive structure to further the urban growth during the High Middle Ages whereas other formal and informal institutions predominated at the national (royal) level when the urban movement declined during the Late Middle Ages.
\end{abstract}

Keywords: Medieval new towns, Formal institutions, Informal institutions, Charters, Royal power, Urban development, French medieval urban organization

\section{Introduction}

Medieval Southwestern Europe saw an outstanding urban expansion between the eleventh and thirteenth centuries and then a decline of the creation of new towns from the fourteenth to the mid-fifteenth century. The study of these two urban trends has been the subject of a great deal of research. However less is known about the institutions that shaped them. (Note 1) The present paper aims to contribute to the understanding of these two urban movements by drawing on the example of medieval France through both historical records and the analysis of institutions. Given the informational impediments (or transaction costs) of the real world, the formal institutions (for instance, local constitutions, statutes, laws, individual contracts, and property rights) are incomplete rules. As a result, informal institutions (for instance, conventions, ethical rules, cooperative behaviours, collective action, social capital, norms and networks) supplement the formal ones. The paper shows that the urban growth of the High Middle Ages was related to specific formal and informal institutions prevailing at the local level (seigneuries or royal private domain) whereas the collapse of the urban expansion in the Late Middle Age was associated with other formal and informal institutions acting at the national level (kingdom).

\section{The Foundation of Medieval New Towns}

In its early stages, a new town was a village community created by a central authority (king or overlord) on his wildland to meet the needs of growing populations and to further both its own benefits and the common interests of the inhabitants (Hoffmann, 1989, p. 437). A lot of new settlements appeared in Europe from the closing decades of the tenth century to the fourteenth century. Their generic designations were the following normalized words: ville neuve (villa nova, new town, villeneuve) or bourg (burgus, burg) and their derivatives. The French (and European) new urban settlements of the High Middle Ages essentially developed from three beginnings: (a) those that grew up around castles or religious houses, (b) those that continued on from ancient settlements sometimes old oppida (fortified places or enclosures) -, and (c) those that sprang up in uninhabited areas at propitious locations (for instance, a natural harbour, river ford, seashore, meander, confluence, or a plateau) and/or at favourable points where a major crossroad, a trading post or a ferry crossing acted as a pre-urban nucleus (Gruber, 1989, pp. 321-322; Reyerson, 1989 p. 312, p. 316). Historical evidence has shown that burgs would correspond to cases (a) and (b) while new towns built ex nihilo would refer to case (c) (Balard, Laurioux, Le Jan, \& Le Mené, 2003, p. 34).

The rise of such new agglomerations essentially stemmed from economic and/or political causes although some of them had also spiritual or military motivations. Basically, due to population growth and technical 
improvements, human settlements had become too dense on the ancient arable land. The aim of the founders kings, princes and overlords - was to create new settlements to accommodate the colonists (hospites) who came to clear the wastes (Ganshoff \& Verhulst, 1966, p. 296; Duby, 1974, p. 200). The former became conscious that urban growth could provide more assets than rural manors by receiving more of a greater number of persons (Chédeville, 1980, p. 157).

The founders of the early Middle Ages towns restricted the choice of new settlers, with noble and/or powerful people (elites) being generally not accepted. This selection aimed to reduce the number of privileged town-dwellers who could protest at paying taxes and consenting rulers' decisions. In addition, the founders favoured the arrival of peasants by confirming that the latter will become free people. They generally populated their new settlements at the expense of neighbouring seigniorial territories. Through emphyteutic leases and in return for an annual fee, the settlers received plots of land surrounding the community, the land granted being free from transfer rights (Chédeville, 1980, pp. 157-158). The colonists participated in collective action, mainly the construction of buildings for sales, meetings, and others activities. In particular, they collectively built sheltered town halls with weighing and measuring areas (these covered town halls were generally over an open ground floor and their higher floor served for the merchant organizations), houses for the octroi (toll), warehouses, large workshops and, possibly, fortified walls (Gruber, 1989, p. 329). The urbanism of these early medieval foundations is generally characterized by a grid outline. However no grid-patterned villages were also founded such as linear ones (street-villages and villages shaped on the basis of the fishbone pattern) and circular villages (these circulades developed in Languedoc-Roussillon between the 1000's and the 1130's) (Cheyette, 1989, p. 446).

\subsection{The Creation of the Tenth- to Twelfth-Century New Towns}

Early medieval new urban communities took place-names composed of several basic designations (the standardized terms of villeneuve or bourg and their derivatives) but also of other normalized appellations according to the causes or the place of the settlement. In previously uninhabited areas some villages, resulting from collective clearance, have a denomination partly composed of the term essart or essard (assartum, assart, land brought into cultivation) and its associated appellations or of the word abergement (albergamentum, accommodation) and its derivatives. (Note 2)

When the rise of burgs was due to the presence of a castle, historical evidence has show that lords' motivation was to attract and protect traders and markets. From 1074 but especially from 1150, a closed or unenclosed cluster of cabins at the foot of a castle emerged mostly in the southern west of France. Such small pre-urban agglomerations frequently became villages or small towns known as castelnaux (castrum, castellum, and castle) and its related compound names or its multifarious designations (with the words castel and château among others) (Derville, 2000, p. 48).

Another type of new community was voluntarily built for spiritual reasons as well as for economic and political motivations. Actually, on remote regions, given the significance of the "Peace of God", small pre-urban formations provided by religious houses frequently acted as nuclei for town-formations. Basically, a right of asylum was widened to an area large enough to surround a village. In the southern west of France, these communities, mainly built from 1050 to 1130 , took the generic name of sauveté (salvitas, salva terra, "site of refuge or asylum") and were often specifically named Sauveterre, Salvetat, Salvy or had denominations mainly connected with the place; in Brittany, similar ecclesiastical territories (the minihis) appeared from the ninth century (Ourliac, 1949, p. 271, p. 277; Reyerson, 1989, p. 316). The motivation of the founders was to cultivate and protect lawless areas by means of banishment of troublemakers, wrongdoers and marauders from the sauveté (Langlois, 1964, p. 68; Fourquin, 1979, pp. 475-476; Derville, 2000, p. 48). Military orders - in particular Hospitallers and Templars - founded numerous sauvetés and thereby improved collective security against robbers and looters in the nearby wildlands. (Note 3) The direct Capetian kings and overlords also founded sauvetés in unpopulated tracts of land so market out. Concretely, the founder set up four wooden crosses at the four cardinal points as landmarks at the corners of a zone surrounding the future sauveté. They associated with the territorial landholder through a formal and perpetual written arrangement or act known as pariage (or paréage) (Duby, 1998, p. 28; Fourquin, 1975, pp. 480-483; Mousnier, 1992, pp. 102-105). This pariage was a partnership (co-lordship) concluded forever where one party supplied the land while one or two other persons provided the powers and the acquaintances necessary to find the colonists and the money to settle them. These pariages set the sharing rules. They defined land share as well as the rights on the land (Saint-Blanquat, 1949, p. 286; Ganshoff et al., 1966, p. 295). This formal institution forecasted the settlement and protection of newcomers, defined the rules of revenue sharing between the contractors, and determined the charges that the potential holders of each lot had to pay. The founders offered to the "colonists-peasants" complete freedom 
(libertates) regarding personal status, military service and certain taxes. Later, during the thirteenth century, sauvetés generally enjoyed charters of privileges and had high autonomy towards the territorial landlords since the founders frequently selected consuls to govern the community. Yet, many sauvetés founded in inauspicious places disappeared; several others poorly subsisted, while the others received the status of bastide. However the major part of bastides was founded ex nihilo (Ourliac, 1949, p. 273, p. 276; Fourquin, 1975, p. 479, p. 540; Balard et al., 2003, p. 241).

\subsection{The Emergence of the Thirteenth-Century Bastides}

The bastides (bastidae, planned towns) were originally set up for economic purposes and/or as the result of the population growth and of the subsequent clearing in the South of France, mostly in Midi-Pyrénées, Aquitaine, and Languedoc. Later, some bastides were also established or fortified for political motivations or military reasons to delimit or protect a territory. On the whole, from around three hundred and fifty to more than five hundred bastides scattered in the South of France, depending on how wide the definition is extended. (Note 4) The majority of them were built from c.1222 (the first was Cordes-en-Albigeois) to c.1370 (the more recent was Labastide-d'Anjou), and intensively from c.1230 to c.1320 (Saint-Blanquat, 1949, p. 279; Derville, 2000, p. 48; Balard et al., 2003, p. 30). Two major historical events accelerated the development of bastides in the thirteenth century: the crusades against the Cathars and the Anglo-French discord that eventually led to the Hundred Years War (1337-1453). First, during the Albigensian (or Cathar) crusades (1209-1255) and after them, the Capetians and their opponents created numerous bastides between the valleys of the Garonne and the Tarn, in the Ariège region, Quercy, Rouergue, and Languedoc. (Note 5) Second, regarding the Anglo-French conflict, some earlier bastides along the French and English frontier in the Guyenne area, usually without initial fortification, became often fortified centers to serve as garrison towns and outposts when this region was under the kings of England (Higounet, 1948). The settlement of around two dozen of new bastides in Guyenne (principally between the Dordogne and Dropt rivers) aimed to define areas of influence within this contested province, and especially delineated administrative and jurisdictional boundaries. They defended frontiers until 1337 when the Hundred Years War officially started (Wagner, 2006 p. 41). During this period, many bastides changed hands between the English and French, some several times.

The twelfth- to fourteenth-century bastides were built by means of three main organizational forms. First, a territorial lord could be both the owner and the founder of a bastide. In that case, the landowner-founder (mainly, the counts of Toulouse, other overlords, the Templars, and the Cistercians) undertook alone the task to choose the site of the new village or town, to recruit colonists, and to provide colonists with houses, feed, and tools throughout the first months. He paid for the laying out and levelling of the streets, for the public buildings (walls and market hall) and other economic facilities (for instance, mills, baker houses, and warehouses) (Gruber, 1989, p. 324). In contrast, in a second organizational type, the founder of the bastide (the king, his seneschal, or an overlord) associated with the territorial landholder through an individual contract (the so-called pariage). Lastly, and third, the founder could purchase the future site. By means of an act of buying, the administration of the bastide and the subsequent revenues were only assigned to the purchaser. (Note 6)

Once the pariage or the act of buying was signed, the surveyors planned the bastide and delineated plots to be distributed among the future residents. The settlers built their house in a specific manner and within a specified time. These norms of urbanism were explicit rules determining the expected action of the settlers. The normalized grid plan could vary in order to subordinate it to the natural contour of the site. Generally, the city plan of a typical bastide was a layout of intersecting streets and lanes. The bastides' boundaries usually approximated a rectangle or a square where streets, habitually straight and meeting at right angles (frequently with principal and secondary streets of proportionate dimensions), divided the area into blocks (insulae) of houses; in the rear there were gardens, and more far cultivated fields and commons. In other words, their urban plan furthered economic uniformity since initially residents held approximately the same possessions. As a result the grid layout facilitated the tax collection (Randolph, 1995). In addition, the bastides have a (central) marketplace surrounded by arcades through which the axes of the (primary) streets pass (Gruber, 1989, p. 324; Heers, 2004). Finally, bastides provided a significant part of the lords' and founders' revenues through taxes on production and trade. The fact that the town' administrators (consuls) met in the town hall shows their role in the economic life.

Bastides' founders selected settlers and generally did not receive noble people who could balk at paying taxes and accepting towns rules (Bernard, 1992, p. 20). The future residents were encouraged to cultivate the delineated plots around the bastide, which in turn enticed travellers and traders. A few years after the pariage or the act of buying that changed the legal status of land, the founders generally granted charters of freedom. 


\section{The Development of the Medieval New Towns}

New towns negotiated collective liberties (or privileges, rights) from the territorial landlords. (Note 7) However, the process was manifold. In some cases, certain territorial landowners did not voluntarily consent to these arrangements and had difficulty to cede their policymaking power in return for municipal authority or for royal political support. In most cases, a series of statements constituted a written record, called charter. Unlike the acts of pariage, these charters were granted by the strongest power, regardless of what it provides: the safety of the community, the guarantee of the municipal administration, the land, or jurisdictional rights (Saint-Blanquat, 1949, p. 286). By and large, the promulgation of charters dates from the twelfth and thirteenth centuries and was common in all areas. (Nevertheless, from the eleventh century, liberties without charters were sometimes bestowed to new urban communities, in particular between the Seine and the Charente; in that case the founders promulgated new customs or other formal rules). Although charters initially aimed to gain freedom from arbitrary justice, unlawful demands and violence of lords they were also proclamations on many other specific points. They gave status to the population and regulated the daily life of the inhabitants: ownership rights, trade activities with fairs and markets, commodity taxes, penalties for misdemeanours and crimes. The charters were formal institutions that reduced real-world uncertainty. They took the form of codified arrangements including both civil law (stating personal freedom, advantages, obligations, and property rights) and constitutional aspects (the form of the municipal government).

\subsection{Charters as Formal Institutions}

Charter of freedom gave status to the population and specified collective rights, obligations and responsibilities. Basically, the charters' provisions could stipulate three sets of rights: civil or personal rights (mainly, suppression of personal subjection and limitation of arbitrariness), economic rights (regarding taxation and trade), and administrative, legal, and political rights (conferring more or less self-governance). Nevertheless, certain new communities (in particular, the "bourgeois towns" and towns with a "charter-law") only benefited from the first two types of rights and therefore had a moderate or low autonomy towards the local seigniorial power (Saint-Blanquat, 1949).

First, as regards civil liberties, charters generally granted freedom to groups of people, seldom to individuals. Negotiators sometimes disagreed. Finally, the restriction of the arbitrary will of the lord had the effect of suppressing the signs of servile charges for a group of persons living in the same seigneurie (Ganshoff et al., 1966, p. 336; Sivéry, 2004, p. 43).

Second, medieval town decision rights redistribution facilitated economic exchanges. The economic and fiscal collective rights referred to the limitation of unlawfully demands of lords, and consequently to the free movement of people and goods, lower constraints regarding land and buildings, and the codification of fees, taxes, tolls and other obligations. In particular, these fiscal privileges referred to exemption or reduction of feudal taxes, tolls and other dues burdening the inhabitants. Thus, on the one hand, the town governments themselves codified, reduced, or suppressed taxes and obligations to entice colonists who gained private property rights through the grant of plots of land. On the other hand, these local governments developed municipal taxes such as the passage tolls on paths, roads, and waterways (particularly on compulsory places such as bridges, fords, crossroads, passes, harbours, and towns entrances) as well as the toll booth (termed tonlieu, teloneum) levied to participate to markets and fairs, make transactions, and pay the supervision of weights and measures (Fossier, 1997, pp. 374-375; Roux, 2004, p. 27).

Third, the charter could also establish interwoven legal, administrative, and political rights. Local governments were charged with the control of the administration and the application of justice. The charter wisely delineated the local lords' power vis-à-vis both the representatives of the monarch or overlords and the ones of the town dwellers. The new communities' founders, or their representatives, yearly selected the town councillors, with various nuances according to space and time. The role of the latter in the economy consolidated when the covered town hall of the new community evolved to accommodate the municipal boardroom (communal or consular room) upstairs.

The new towns had different levels of autonomy towards the local lords. For instance, on the one hand, some bastides, only endowed with markets and shops, turned out to be villages; they acquired some rights but a low autonomy towards the local seigneurie. In contrast, other bastides prospered and grew by means of courts and fairs. The latter constituted a network of secondary towns (predominantly, small and medium-sized towns) that formed intermediaries between some big old towns and rural villages. Some of those bastides became eventually large urban cities. Among this network of satellite agglomerations reliant on the large towns, some were royal bastides, namely organizations existing thanks to organized royal enforcement by means of royal officials and courts. 


\subsection{Royal Government' Expansion}

Regarding the representatives of the territorial authority, the charter could state that the founder entrusted the governing and application of justice to a royal agent, called bailiff or seneschal (Langlois, 1964, pp. 71-74). In fact, royal taxes were increasingly levied. Notably, at the beginnings of the thirteenth century, Philip Augustus established over his own royal land a network of administrative, fiscal and legal jurisdictions, called bailiwicks (bailliages) in the north or seneschalships (sénéchaussées) in southern provinces - themselves based on the earlier medieval fiscal divisions: the baillies (Le Goff, 2005, p. 106). In other words, the crown consolidated its political property rights. Concretely, such king's officers were generally appointed for one year, however renewable, and dismissed if necessary. In return, they had to pay the king and/or the other town founders (mainly counts) the price agreed annually. To do this, these representatives had to generate revenues from taxes on trade (including also commissions paid for debt enforcement), fines received for punishing criminal acts (crime, threat, insult, theft, shoplifting, damage, and commercial fraud such as the falsification of weights and measures or the adulteration of foodstuffs), payments for the remission of sentences of banishment, and a myriad of other transfers. Their royal jurisdictions, namely bailiwicks and seneschalships, were generally subdivided into either royal provostships, viscounties, or castellanies. However, it seems that some provosts, viscounts, castellans, as well as a large number of subaltern municipal agents (for instance, local administrators such as receivers, foresters, money-changers, sergeants, judges, and notaries) committed exactions. Subsequently, Louis IX of France dispatched investigators (the enquêteurs-réformateurs) whose records finally attested such abuses (both in new and old towns). As a result, he signed the great ordinance of 1254 to moralize the behaviours of the urban rulers. The increasing centralized royal government decided to control them through new empowered officials. Lastly, these new royal professionalized officials had policy behaviors inconsistent with those of local citizen-rulers (the merchant and bankers elites).

Finally, historical data has shown that some of these settlements gave rise to towns, but most remained in a state of mere villages. (Note 8)

\section{The Decline of the Creation of New Towns}

After the urban growth of the High Middle Ages, the waning of the movement started around the year 1300. This downward trend was nonlinear, with differences in time and space. Indeed, the apogee of the sauvetés had been reached during the first third of the twelfth century whereas the one of the bastides began before the mid-fourteenth century (Bernard, 1992, p. 24; Derville, 2000, p. 48). The collapse of the trend of urban expansion had complex and interlinked causes. On the one hand, some institutional and organizational changes took place when Capetians governments enlarged their control of municipal governments, contributing to weaken the feudal system. (Note 9) To do this, three efficient devices were particularly efficient: (i) the royal confirmation of seigniorial charters from the late twelfth century; (ii) the creation of the social organization of the "bourgeois of the king" in the late-thirteenth-century; (iii) and, from the mid-fourteenth century, the emergence of socio-political organizations such as the "good towns of the king". On the other hand, the fourteenth and fifteenth centuries were a period of economic, social and political crises in Western Europe.

\subsection{The Royal Confirmation of Seigniorial Charters}

Philip Augustus not only confirmed the charters previously granted by his predecessors but also confirmed the ones formerly conceded by other seigniorial lords. This institutional change applied against the opposing lords in annexed areas as well as in other regions. Thereby, the king interfered in affairs of the lords' towns and increased royal governance and taxation. This device to consolidate his power was also used by his successors (Di Corcia, 1978, p. 209). The lords were no longer encouraged to create new communities since the latter were recovered by the king through the confirmation of the charters. In addition, such confirmations were also useful to strengthen monarchy by means of the citizens themselves, the so-called "bourgeois of the king".

\subsection{The "Bourgeois of the King”: a Social Organization through Ethical Rules and Self-Commitment}

Until the first third of the twelfth century, a citizen who left his hometown became subject to his new seigniorial jurisdiction. However, through royal confirmations of charters, a social category emerged in 1134 during the reign of Louis VI: the one of the "bourgeois of the king". Clearly, when royal confirmation of charters occurred, citizens living in seigniorial lands could gain the right to be protected by the crown in case of a trial before the seigniorial justice. To do this, the individual took the oath of entry into the bourgeoisie of the king and received a certificate (De Corcia, 1978, pp. 209-210). Later, by virtue of royal letters of protection, Louis IX extended the status of the "bourgeois of the king" (burgesias regni nostri, bourgeois du roi, citizens of the king). While residing in the territory of a lord, the "bourgeois of the king" paid a small fee to come under the royal justice. Consequently, unlike the ordinary citizens who used their privileges only in a delineate area, the citizens of the 
king enjoyed their rights everywhere in the kingdom (Prévité-Orton, 1975, p. 716; Di Corcia, 1978, pp. 209-212). By means of this category, the crown thereby enlarged its jurisdiction although towns continued to benefit from the privileges bestowed not only by the last Capetians of the direct line but also by the other lords. In 1287, Philip IV promulgated an ordinance strengthening this status. At the end of the process all bourgeois were bourgeois of the king (Di Corcia, 1978, p. 212). However, note that the group of the "bourgeois of the king" was not only a category with a title but also a specific social organization. Furthermore, it is worthwhile to note that the informal institutions that underlay this organization took the form of ethical rules or codes of conduct whose enforcement was in fact the self-commitment (given the oath) of the bourgeois themselves.

\subsection{The "Good Towns of the King": Socio-Political Organizations through Conventions and Self-Enforcement}

Economic and political reasons urged the kings to transform the institutional role of the towns. The increasing centralized royal power furthered specific urban centers known as "Good towns of the king" (Bonnes villes du roi) from the late thirteenth century. Chevalier (1982) listed about 240 French good towns at that time although no clear definition exists. Such "good towns" were generally medium-sized agglomerations having administrative autonomy. They were controlled by the monarchy to provide refuge for population and military infrastructure during the wars, as well as to guarantee royal fiscal receipts. (Note 10) It is worthwhile to highlight that such "good towns" were also socio-political urban organizations active politically and promoting urban entity. Such organizations had no specific definition or consciously created rules. In reality, they were underpinned by conventions, namely by self-enforcing informal institutions. These conventions were informal norms of conduct that advocated urban entity and civic mentality. The "good towns of the king" developed civic unity thanks to self-enforced cooperative behaviors, for instance social capital - such as trust and sharing of information and knowledge between the dwellers themselves but also between the latter and the royal officials.

\subsection{Natural Disasters, Revolts, and Wars}

From the fourteenth century, significant catastrophes afflicted French (and European) towns and countryside in varying levels. The causes were both climatic and human. First, natural disasters such as freezing winters, rainy springs, flooding, and summer droughts brought about crop failures and subsequently food shortages, malnutrition, diseases, epidemics (in particular the Black Death between 1347 and c.1350) and famines (for instance, the Great Famine of 1314-1317, and the ones of 1342-1343, 1351, 1360, 1363-1364, 1369-1370, 1374, and 1382). The onslaught of the plague and epidemics gave way to a population decline. Indeed, by the middle of the fourteenth century and until around the mid-fifteenth century, most towns in some French areas lost a third of their inhabitants; deserted villages could be counted in the hundreds (Cheyette, 1989, p. 446; Favier, 1993, p. 969). Second, these disasters, and the subsequent demographic collapse, were aggravated by human motives. The Hundred Years War (1337-1453) struck France and complicated the subsistence problems in the warring areas while fiscal affairs exacerbated urban (and rural) uprisings. In particular, arbitrary tax increase, propagation of direct and indirect taxes, and illegal enrichment of the kings and overlords were echoed in popular revolts in the 1380's. (Note 11) Rebels protested against misgovernment and denounced unfair taxation, corruption, misuse of taxes by the local and regional authorities, exploitation of people's work, and loss of rights. They asked for direct control over the urban policy and therefore required political representation.

Subsequently, in the aftermath of these events, the fourteenth-century kings frequently interfered in local political decision-making to reshape the urban institutions. Such communities lost their municipal rights and were henceforth under the control of royal officials. In addition, other towns lost their municipal "autonomy" due to poor governance and indebtedness of urban governments. (Note 12) Later, in the fifteenth century, other disasters - such as the major famines of 1408, 1420-1421, 1432, and 1438 - plagued France and many European regions. The fourteenth- and fifteenth-century natural calamities stymied the spread of urban revival of the High Middle Ages. More generally, throughout the Late Middle Ages, by and large, institutional change, revolts, wars, and natural disasters led to the fact that the eleventh- to thirteenth-century French urban expansion trend came to an end.

\section{Conclusion}

From a positive perspective, historical institutional analysis is likely to further understanding of the medieval urban question characterized by the two following movements: the urban growth during the High Middle Ages and the decline of the urban expansion during the Late Middle Ages. Concerning the first movement, the kings, princes and overlords founded new urban communities due to growing populations as well as political, military, and socio-economic reasons. The paper shows that these new communities sprang up through formal and informal institutions acting at a local level (seigniorial lands, private royal lands). In particular, the urban revival was associated with: (i) formal institutions - such as charters, statuses of liberty for people (personal freedom) 
and for communities (more autonomy vis-à-vis the territorial lord), individual contracts (co-lordships), private property rights for settlers, and political property rights for the municipal elites - and (ii) informal institutions: collective action between local actors (founders, landowners, settlers) to build the new communities, norms (regarding towns' names and rational urbanism), and networks of communities.

In contrast, the second urban movement corresponded to a dramatic demographic decrease caused by natural disasters, famines, epidemics, conflicts, and wars. The paper shows that the decline of the urban expansion was related not only to famines and wars but also to the increasing royal power consolidated through institutions active at the national level. Such institutions encompassed: (iii) formal institutions such as royal confirmation of seigniorial charters -, and (iv) informal institutions linked to the formal ones, for instance: ethical rules or codes of conduct (with the self-commitment of the "bourgeois of the king") and conventions (through the development of the "good towns of the king" and their self-enforced behaviours).

From a policy point of view the paper presented here is interesting as well. Its results offer insights that apply beyond the question that it has focused on. Medieval institutions are the precursors of the modern urban policies. However, the meaning of the word "town" has evolved. Now, a town is composed of one or more communes, the commune being the lowest level of administrative division. (Note 13) A town can refer to an agglomeration encompassing suburban and satellite areas. The urban policy created organizations and institutions to promote the nine French new towns developed from the mid-1960s for demographic and economic reasons. (Note 14) More broadly, the current urban policies (through national agencies and programmes) further institutions to advocate urban contract for social cohesion, reduction of public local debts, and solidarity not only between people but also between territories. How formal and informal institutions are linked to each other and what effect they have on the evolution of the recent European and global new towns are among the most interesting issues that lie ahead.

\section{References}

Balard, M., Laurioux, B., Le Jan, R., \& Le Mené M. (2003). Dictionnaire de la France médiévale. Paris: Hachette.

Bernard, G. (1991). The bastides of south-west France. (Translated by M. Mills). Toulouse: Diagram.

Bisson, T. N. (1989). Medieval France and her Pyrenean neighbours: Studies in early institutional history. London-Ronceverte: Hambledon Press.

Braudel, F. (1992). Civilization and capitalism, 15th-18th century: The structure of everyday life. (Translated by S. Reynolds). Berkeley and Los Angeles: University of California Press.

Brennan, G., \& Buchanan, J. M. (1985). The Reason of rules. Constitutional political economy. Cambridge: Cambridge University Press.

Brennan, T. (2001). Town and country in France, 1550-1750. In S. R. Epstein (Ed.), Town and country in Europe, 1300-1800 (Chapter 11). Cambridge: Cambridge University Press.

Chédeville, A. (1980). De la cité à la ville, 1000-1150. In A. Chédeville, G. Duby, J. Le Goff, \& J. Rossiaud (Eds.), Histoire de la France urbaine (pp. 30-187). Paris: Seuil.

Chevalier, B. (1982). Les bonnes villes de France du XIVème au XVIème siècle. Paris: Aubier-Montaigne.

Cheyette, F. L. (1989). Villages: Settlement. In J. Strayer (Ed.), Dictionary of the Middle Ages (pp. 442-447). New York: Charles Scribner's Sons.

Congleton, R. D. (2007). From royal to parliamentary rule without revolution: The economics of constitutional exchange within divided governments. European Journal of Political Economy, 23, 261-284.

Derville, A. (2000). La société Française au Moyen Âge. Paris: Presses Universitaires du Septentrion.

Di Corcia, J. (1978). Bourg, bourgeois, bourgeois de Paris from the eleventh to the eighteenth century. Journal of Modern History, 50 (2), 207-233.

Duby, G. (1974). The early growth of the European economy: Warriors and peasants from the seventh to the twelfth century. London, New York: Cornell University Press.

Duby, G. (1998). Rural economy and country life in the medieval West. (Translated by C. Postan). Philadelphia: University of Pennsylvania Press.

Favier, J. (1993). Dictionnaire de la France médiévale. Paris: Fayard.

Fossier, R. (1997). The structuring of society. In R. Fossier (Ed.), The Cambridge illustrated history of the Middle Ages, 950-1250 (Chapter 8). Cambridge: Cambridge University Press. 
Fourquin, G. (1975). Le premier Moyen Âge (Part 3); Le temps de la croissance (Part 4); Au seuil du XIVème siècle (Part 5). In G. Duby \& A. Wallon (Eds.), Histoire de la France rurale. Vol. 1: Des Origines à 1340. Paris: Seuil.

Fourquin, G. (1979). Histoire économique de l'Occident médiéval. Paris: A. Colin.

Furubotn, E., \& Richter, R. (2001). Institutions and economic theory. The contribution of the new institutional economics. Ann Arbor, Michigan: University of Michigan Press.

Ganshoff, F. L., \& Verhulst, A. (1966). Medieval agrarian society in its prime. §1. France, the Low Countries, and Western Germany. In M. M. Postan (Ed.), The Cambridge economic history of Europe. Vol. 1. Cambridge: Cambridge University Press.

Gendry, M. (2010). Les minihis en Bretagne entre le IXème et le XIIème siècle: Des territoires monastiques sacralisés? Annales de Bretagne et des Pays de l'Ouest, 117(2), 25-55.

Gruber, S. (1989). Urbanism, western European: Architectural aspects. In J. Strayer (Ed.), Dictionary of the Middle Ages, (Pt. 12, pp. 320-331). New York: Charles Scribner's Sons.

Heers, J. (2004). La ville au Moyen Âge en Occident. Paysages, pouvoirs et conflits. Paris: Hachette.

Higounet, C. (1948). Bastides et frontières. Le Moyen Âge, 54, 113-131.

Hilton, R. H. (1995). English and French towns in feudal society: A comparative study. Cambridge: Cambridge University Press.

Hodgson, G. M. (2006). What are institutions? Journal of Economic Issues, 40 (1), 1-25.

Hoffmann, R. C. (1989). Villages: community. In J. Strayer (Ed.), Dictionary of the Middle Ages (Pt. 12, pp. 437-441). New York: Charles Scribner's Sons.

Langlois, Ch. V. (1964). History. In A. A. Tilley (Ed.), Medieval France: A companion to French studies. (Chapter 2). Cambridge: Cambridge University Press.

Le Goff, J. (1998). Apogée de la France urbaine médiévale. In A. Chédeville, J. Le Goff, \& J. Rossiaud (Eds.), Histoire de la France urbaine (Vol. 2: La ville en France au Moyen Âge). Paris: Seuil.

Le Goff, J. (2005). The birth of Europe. (Translated by J. Lloyd). Oxford: Blackwell Publishing Ltd.

Mollat, M. \& Wolff, P. (1973). The popular revolutions of the late Middle Ages. (Translated by A. L. Lytton-Sells). London: Allen and Unwin.

Mousnier, M. (1992). Bastides de Gascogne Toulousaine, un échec? In Villages et villageois au Moyen-Âge, Série Histoire Ancienne et Médiévale, 26, Paris.

Nee, V. (1998). Norms and networks in economic and organizational performance. American Economic Review, 88(2), 85-89.

North, D. C. (1990). Institutions, institutional change and economic performance. New York: Cambridge University Press.

North, D. C. (1991). Institutions. Journal of Economic Perspectives, 5(1), 97-112.

Ourliac, P. (1949). Les Villages de la région Toulousaine du $12^{\text {ème }}$ Siècle. Annales: Economies, Sociétés, Civilisations, 3, 268-277.

Prévité-Orton, C.-W. (1975). The shorter Cambridge medieval history (Vol 1: The Later Roman Empire to the Twelfth Century). Cambridge: Cambridge University Press.

Randolph, A. (1995). The bastides of southwest France. The Art Bulletin, 77(2), 290-307.

Reyerson, K. L. (1989). Urbanism, western European. In J. Strayer (Ed.), Dictionary of the Middle Ages (Pt. 12, Tome 1, pp. 311-320). New York: Charles Scribner's Sons.

Rossiaud, J. (1998). Crises et consolidations, 1330-1530. In Histoire de la France urbaine. (Vol. 2: La ville en France au Moyen Age). Paris: Seuil.

Roux, S. (2004). Le monde des villes au Moyen-Âge. Paris: Hachette.

Saint-Blanquat (de), O. (1949). Comment se sont créées les bastides du sud-ouest de la France? Annales: Economies, Sociétés, Civilisations, 3, 278-289.

Sivéry, G. (2004). Rural society. In: The new Cambridge medieval history: c.1198-c.1300. In D. Abulafia (Ed.). (Vol. 5, pp. 38-49). Cambridge: Cambridge University Press. 
Vanberg, V. J. (2005). Market and state: The perspective of constitutional political economy. Journal of Institutional Economics, 1 (1), 23-49.

Wagner, J. A. (2006). Bastides. In Encyclopaedia of the Hundred Years War. Westport, Connecticut, London: Greenwood Press.

Williamson, O. E. (1985). The economic institutions of capitalism. Firms, markets, relational contracting. New York: Free Press.

Wolfe, M. (1999). Siege warfare and the bonnes villes of France during the Hundred Years War. In I. A. Corfis and M. Wolfe (Eds.), The medieval city under siege. Suffolk: St. Edmundsbury Press Ltd.

\section{Notes}

Note 1. On institutions, see North, 1990, 1991; Furubotn \& Richter, 2001; Hodgson, 2006; Nee, 1998; Williamson, 1985.

Note 2. For details regarding the place-names see Fourquin, 1975, pp. 477-480; Ganshoff \& Verhulst, 1966, p. 296.

Note 3. For instance, the Hospitallers' commanderie located in the Toulouse area possessed more than fifty sauvetés and the commanderie situated in the Comminges - region in the foothills of the Pyrénées - around forty. From about 1130 the Templars cleared forest on the Garonne's left bank to establish numerous sauvetés.

Note 4. For ease of understanding four main types of founders may be considered. Firstly, the Capetian kings of France (mainly Louis IX, Philip III and Philip IV) created more than 69 "royal bastides" (chiefly between c. 1250 and 1350) while the seneschal Eustache de Beauharnais (royal appointee at Toulouse) built around 22 ones (bastides sénéchales) in the 1280's. Meanwhile, in the Guyenne area, the English kings (Edward I, Edward II, and Edward III of England) founded at least 64 royal bastides. Secondly, the counts of the town of Toulouse set up at least 71 bastides (bastides comtales): at least 17 bastides were established by Raymond VII and 54 bastides (called bastides Alphonsines) by Alphonse de Poitiers (brother of Louis IX of France) in the mid 1200's. Thirdly, religious institutions developed more than one hundred bastides. Fourthly, local lords constructed numerous seigniorial bastides to assert their independence from the French and English (Plantagenet) kings.

Note 5. In particular, bastides developed under the terms of the first Treaty of Paris (1229), which permitted Raymond VII (Count of the Toulouse area) to build new towns in his territories shattered by the Cathar wars.

Note 6. For instance, the Count Alphonse de Poitiers - the brother of Louis IX of France - preferred to buy the territory of his foundations; he signed a pariage only if necessary (Saint-Blanquat, 1949, p. 283).

Note 7. The term of 'privilege' (libertates, franchises) is used by historians, synonymous with the terms of freedom (Le Goff, 1998).

Note 8. Actually, no town reached the figure of 50,000 inhabitants except Paris with 200,000 dwellers; and only 40 towns exceeded the threshold of 10,000 inhabitants (Roux, 1994; Balard et al., 2003, p. 272).

Note 9. On the theory of constitutional economics, see Brennan \& Buchanan, 1985; Vanberg, 2005; Congleton, 2007.

Note 10. Chevalier, 1982; Bisson, 1989, p. 82; Braudel, 1992, p. 520; Hilton, 1995, p. 4; Wolfe, 1999, p. 50; Brennan, 2001, p. 250.

Note 11. The Harelle revolt in the city of Rouen in February 1382 was followed in March by the Maillotins revolt in Paris and many similar uprisings in northern agglomerations (Amiens, Caen, Dieppe, Orléans, Rheims, among others). In the south, the popular revolt of the Tuchins broke out in Languedoc between 1381 and 1384 and in Auvergne between 1384 and 1389 (Mollat \&Wolff, 1973).

Note 12. Some towns asked for the suppression of their charter by the king (Rossiaud, 1998, p. 400).

Note 13. Several forms of cooperation between communes have emerged when the latter have banded together to form an intermunicipal consortium.

Note 14. The nine new towns created were: (i) near Paris: Cergy-Pontoise, Evry (-Ville-Nouvelle), Marne-la-Vallée, Sénart, Saint-Quentin-en-Yvelines; (ii) near Lyon: L'Isle-d'Abeau; (iii) near Lille: Villeneuve d'Ascq; (iv) near Marseille: Ouest Provence (former Rives de l'Etang de Berre); and (v) near Rouen: Val-de-Reuil. To built such towns, an organization (the "établissement public d'aménagement" (EPA)) was set up. It consists of state officials responsible for urban development projects, purchase of land, and resale to investors. This organization has implemented various contracts and rules through parternships between the state and territorial administrations. 